\title{
МОНИТОРИНГ ПРАВОПРИМЕНЕНИЯ КАК ИНСТРУМЕНТ ПОВЫШЕНИЯ ЭФФЕКТИВНОСТИ РЕАЛИЗАЦИИ НОРМАТИВНЫХ АКТОВ
}

\author{
(c) 2021 Ларионова Карина Азатовна \\ аспирант \\ Астраханский государственный университет, Россия, Астрахань
}

Статья посвящена исследованию юридической категории правового мониторинга в контексте его легального проявления: мониторинга правоприменения. Выявлены сильные и слабые стороны его проявления, определена необходимость модернизации правовых корректировок функционирования института, предложены перспективы развития законодательства, с целью повышения эффективности правовых актов.

Ключевые слова: правовой мониторинг, мониторинг правоприменения, эффективность правовых актов, правовая норма.

Динамично меняющаяся действительность окружающего мира ставит перед законодателем задачу оперативного реагирования и формирования правовых регуляторов различных групп правоотношений. Социальный заказ в виде сложившейся определенной группы правоотношений требует создания таких праворегуляторов, которые позволили бы эффективно регламентировать новые горизонты взаимодействия. Попытки законодателя вовремя отреагировать на необходимость принятия нормативных актов автоматически влечет усложнение всей системы законодательства. Кроме того, своевременное принятие правовых норм не может гарантировать их эффективности. Зачастую проблемы юридической техники проявляют себя именно в процессе правоприменения. Уже действующие нормативные акты неизбежно порождают распространение юридических коллизий, что в свою очередь продуцирует конфликтность в правоприменительной практике. В этих условиях вопросы совершенствования юридической техники становятся наиболее актуальными, а такой ее инструментарий, как мониторинг эффективности нормативных актов видится одним из самых значимых в процессе модернизации отечественного законодательства.

Цель исследования заключается в организации анализа легального и доктринального понимания мониторинга правоприменения как инструмента повышения эффективности реализации нормативных актов.

Методология исследования довольно обширна и представлена совокупностью методов научного познания, в частности, диалектиче- ский подход к научному познанию правовых явлений, а также общественных процессов, которые призваны обеспечивать исследование мониторинга правоприменения как инструментария повышения эффективности реализации нормативных актов. В процессе исследования использовались методы анализа и синтеза, формально-юридический, сравнительно-правовой, системно-структурный и т.д.

Правовой мониторинг, как юридическая категория, имеет довольно обширную историографию. Однако, наиболее полное, целостное его определение было дано профессором Российской академии наук, доктором юридических наук, Н. Н. Черногором: «Правовой мониторинг это методически обоснованная комплексная систематическая деятельность уполномоченных субъектов по наблюдению, анализу, оценке качества правотворческого процесса, юридических норм и практики их реализации на предмет достижения поставленных при их принятии целей, а также по прогнозированию путей совершенствования правотворчества и правоприменения» $[4,8]$. Представленное определение позволяет акцентировать внимание на субъектном составе процесса правового мониторинга, этапах его организации и составных элементах механизма, закрепить цель реализации правового мониторинга.

Несмотря на авторский приоритет вышеприведенного определения, не стоит умалять значения иных доктринальных разработок в области правового мониторинга, которые принадлежат Д.Б. Горохову [6, 7], Ю.А.Тихомирову [9]. В работах представленных авторов исследо- 
ваны концепции, методология организации и проведения правового мониторинга. При этом акцент в исследовании правового мониторинга сделан на процедурных элементах организации правового мониторинга с целью повышения качества эффективности нормативных актов. Охват правового мониторинга расширяется за счет включения в механизм правотворческой стадии и определения эффективности правоприменительного процесса.

Интерес представляет тот факт, что легализация организации правового мониторинга заложена в Указе Президента РФ от 20.05.2011 № 657 [2] и Постановлении Правительства РФ от 19.08.2011 № 694 [3]. Анализ представленных документов позволяет констатировать отсутствие легально зафиксированной терминологии правового мониторинга. Кроме того, легализация правового мониторинга, как механизма повышения эффективности функционирования нормативных актов, в соответствии с вышеупомянутыми Указом и Постановлением связана с организацией процесса мониторинга правоприменения. На этом основании логично предположить отсутствие превентивного механизма повышения эффективности юридической техники за счет отсутствия нормативной легализации более объемной системы организации правового мониторинга, который должен охватывать и правотворческий процесс. По этой причине в центре данного научного исследования находится именно мониторинг правоприменения, как юридико-формальная категория повышения эффективности функционирования нормативных актов.

Указанный недостаток правового регулирования не умоляет попыток государственного аппарата повысить качество нормативных правовых актов, исключить их пороки через призму мониторинга правоприменения. В целом это должно приводить к повышению эффективности всего законодательства.

Анализ законодательства, регламентирующего мониторинг правоприменения (прежде всего, Указа Президента РФ и Постановления Правительства РФ), позволяет акцентировать внимание на том, что в фокусе рассматриваемого механизма находятся практически все нормативные акты. Оценке в процессе мониторинга подлежат вопросы взаимодействия нормативных актов, критериальность их соподчиненности (иерархичность), исключение казуистики. Именно мониторинг позволяет обнаружить дефекты правовых актов, имеющиеся в них неточности, неопределенность. Следует акцентировать внимание на том, что в процессе мониторинга детализируется анализ не только и не столько непосредственного прочтения конкретной нормы, сколько особенности ее применения на практике, вследствие чего в зону мониторинга попадают материалы правопрменительной практики.

На основании Указа Президента № 657 и Постановления Правительства № 694 следует заключить, что правовой мониторинг в настоящее время заключается исключительно в мониторинге правоприменения, что не может позволить максимально эффективно выстроить существующие систему законодательства. Сложно отрицать, что наиболее рациональным подходом было бы включение в организацию правового мониторинга всех этапов создания и функционирования правовых актов. Обосновывать целесообразность указанного авторского тезиса излишне: легче предвидеть возможную казуистику и дефект правового акта (нормы права) на этапе его формирования и не допустить дефектную норму к функционированию, чем придать ей юридическую силу, получить конкретную практику ее применения в разрезе с действующими принципами построения правовой системы, проанализировать эту правоприменительную практику и прийти к выводу о дефектности правовой нормы. За пределами очевидности «Сизифова труда» стоят еще и конкретные человеческие судьбы, попавшие в зону действия такой дефектной правовой нормы.

На основании изложенного в рамках данного научного исследования следует сформулировать предложение необходимости детальной правовой регламентации процесса правового мониторинга в целом, включающем этапы становления, принятия и функционирования правовых норм.

Еще одна спорная сложность, на которую обращает внимание Н.Н. Черногор - сужение субъектного состава правового мониторинга. Ученый полагает необходимым расширить его за счет включения иных, помимо исполнительной власти, правотворческих и прежде всего, законотворческих органов, судов, профессиональное юридическое сообщество, представителей науки, бизнеса, гражданского общества и др. [10] Указанная позиция не лишена недостатков. По мнению автора к субъектам правового мониторинга должны быть отнесены те лица, которые обладают, безусловно, таким 
набором компетенций, который позволяет оценить структуру анализируемой правовой нормы, юридико-технологическую конструкцию, филологические особенности изложения, соотнесение с иными функционирующими актами и способными предположить проблемы в практике правоприменения рассматриваемой нормы в случае придания ей статуса действующей.

Тем не менее, идея Н.Н. Черногора расширения субъектного состава правового мониторинга может привести к повышению эффективности правовых актов в том случае, когда специалисты перечисленных им областей (науки, бизнеса и т.д.) будут участвовать в качестве экспертовконсультантов в процессе организации правового мониторинга. Кроме того, повышение качества нормативных актов можно достичь при привлечении представителей науки и бизнеса еще на этапе формирования инициативы и проектов нормативных актов.

Центральным показателем эффективности правового акта должно быть достижение цели, для которой он был сформирован и принят. Целесообразность принятия правовой норм является главным критерием эффективности. В то же время, анализ Методики осуществления мониторинга (Приложение к Постановлению Правительства № 694) позволяет констатировать отсутствие такого критерия. На том, что указанный критерий является ключевым, акцентирует внимание В.В.Астанин [5]. На основании указанного, предлагается внести корректировки в положения п. 8 Методики, включив показатель соответствие цели, для достижения которой был принят нормативный правовой акт, результатам его фактической реализации.

С сожалением также стоит отметить отсутствие системы прогнозирования с целью повышения эффективности функционирования нормативных актов, организованное в рамках правового мониторинга. Система прогнозирования рисков реализации правовых актов в тоже время может существовать и вне механизма правового мониторинга, однако, взаимосвязь институтов и последовательность их применения не вызывает сомнений в целесообразности.

Представленные пробелы в нормативном регулировании правового мониторинга снижают эффективность его применения, а частота подведения итогов правового мониторинга (мониторинга правоприменения) не позволяет говорить об оперативности процесса. Пункт 5 Положения о мониторинге правоприменения
(Приложение к Указу Президента) устанавливает формирование проекта на год и соответственно отчетность по его исполнению также один раз в год, что не позволяет оперативно реагировать на выявленные дефекты в нормативных документах. Это порождает параллельный процесс признания актов недействительными, что сводит весь механизм правового мониторинга к нулевой результативности, в случае, если производство по делам о признании акта недействительным реализуется до принятия мер коррекции дефектных норм. Отставание в выявлении требует пояснений. На практике, предположим, за 2020 год правоприменение войдет в проект только в 2021 году, следовательно, отчетность по мониторингу правоприменения будет представлена уже в 2022 году, что сохраняет функционирование дефектной нормы в течение двух лет.

Подводя итоги проведенного исследования, следует констатировать необходимость модернизации правовых норм, регламентирующих процесс правового мониторинга.

Следует расширить границы правового мониторинга и детализировать механизм путем отражения комплексной юридической категории «правовой мониторинг». Указанные модернизации возможны в условиях расширения существующего механизма мониторинга правоприменения и формирование его как части масштабного процесса правового мониторинга.

Методика реализации мониторинга также нуждается в доработки за счет расширения спектра субъектного состава его участников. В рамках исследования предлагается сформировать принципиально новый механизм экспертноконсультативного характера, предполагающий включение представителей науки, бизнеса и т.д в качестве экспертов правового мониторинга на этапе продуцирования нормотворческой инициативы и заканчивая заключительным этапом правового мониторинга - мониторинга правоприменения.

Требует разрешения вопрос актуализации оперативности мониторинга правоприменения путем формирования ежемесячных проектов планов мониторинга и ежемесячных отчетов о его проведении.

Представленные корректировки законодательства в области организации правового мониторинга в целом и мониторинга правоприменения в частности, позволят повысить эффективность реализации правовых норм. 


\section{Библиографический список}

1. Конституция РФ (принята всенародным голосованием) от 12 декабря 1993 г. (с изменениями, одобренными в ходе общероссийского голосования 01.07.2020) // Российская газета от 04.07.2020 г. № 144.

2. Указ Президента Российской Федерации от 20.05.2011 № 657 (ред. от 25.07.2014) «О мониторинге правоприменения в Российской Федерации» // Собрание законодательства РФ. 2011. № 21. Ст. 2930.

3. Постановление Правительства Российской Федерации от 19.08.2011 № 694 «Об утверждении методики осуществления мониторинга правоприменения в Российской Федерации» // Собрание законодательства РФ. 2011. № 35. Ст. 5081

4. Актуальные проблемы правотворчества: учеб. пособие / Н.Н. Черногор, М.В.Залоило. М.: Институт законодательства и сравнительного правоведения при Правительстве Российской Федерации: юридическая фирма «Контракт», 2018. 144 с.

5. Астанин В.В. Методологические основы мониторинга правоприменения в контексте научной доктрины и требований законодательства // Административное и муниципальное право. 2012. № 4. С. 5-13.

6. Горохов Д. Б. Современное нормативное обеспечение мониторинга в сфере права и статус его результатов // Журнал российского права. 2012. № 9. С. 83-97

7. Механизм правового мониторинга: науч.-практ. пособие / Д. Б. Горохов и др.; отв. ред. А. В. Павлушкин. М.: Институт законодательства и сравнительного правоведения при Правительстве Российской Федерации: ИНФРА-М, 2012. 160 с.

8. Правовой мониторинг: актуальные проблемы теории и практики / под ред. Н. Н. Черногора. М.: Международный юридический институт, 2010. 232 с.

9. Правовой мониторинг: науч.-практ. пособие / под ред. Ю.А. Тихомирова, Д. Б. Горохова. М.: Юриспруденция, 2009. 416 с.

10. Черногор Н.Н., Залоило М.В.Правовой мониторинг: инструментальная ценность и векторы развития // Вестник Московского государственного областного университета. Серия: Юриспруденция. 2018. № 3. С. $8-21$. 